\section{The Editor}

My expectations were aroused by the beginning paragraphs of R.N. Byron's The Fable of the Great Inheritance: Forest Policy in British Columbia, Forestry Chron. June, 1977. Here were the makings of a classic biblical parable, to crystallize the meaning of life in general and B.C. forest policies in particular. The successive brothers were beginning to grasp the true meaning and purpose of their inheritance. But surely some wise person on the second page would improve on these initial gropings. His distilled wisdom would take care of the delighted but perplexed brothers, and by extension, of the managers of B.C.'s forest inheritance.

This person does not materialize. Instead, someone apparently eager to mine more coal, speaking in 1865, asks us to choose between "brief but true greatness" and "longer continued mediocrity". His preference is for the former; he apparently feels that the best goal of all, lasting greatness, is unimportant or unattainable. Finally an economist is asked to emerge from a telephone booth and decide for us how true and how brief our greatness should be.

This is a decidedly flat ending for what began with such promise. Would it not have been preferable to conclude Mr. Byron's narrative differently? Perhaps the five brothers could have continued groping a little longer, received the advice of experts, and decided for themselves on the best and most permanent ways both to use and to maintain their inheritance.

We foresters in B.C. recognize the need for new forest management ideas and policies, but still hope these will evolve within the concept of continuity. We know we can benefit from the contributions of economists, but not to the exclusion of our own hard-earned experience and responsibility. Forgive us if we reject ideas for "brief but true greatness" in connection with our forests.

\section{R.E. Breadon}

\section{Words of Thanks}

Most letters to the Editor are letters of complaint or rebuttal. To make a variation on this theme I feel that 'I should write a note of encouragement and gratitude.

During the past year I have had the privilege of serving as Chairman of the Ottawa Valley Section and as Chairman of the Urban Forestry Working Group \#12. In this capacity I have received several encouraging letters from President Brookman Anderson and his fellow Executives and I have found this most gratifying. This interest, and the efficiency of the Executives, has been an inspiration to me who, in the past, on occasion, has felt somewhat remote from the seat of power. A precedent has been set which, in my view, will contribute significantly to making the CIF the strong national body it truly deserves to be.

In closing, I further want to acknowledge with thanks the support you, the Editor of The Forestry Chronicle, have given to the Urban Forestry Working Group with regard to the collation and editing of papers for the Urban Forestry Special Edition of The Forestry Chronicle.

Erik Jorgensen

\section{The Editor}

Judging by articles and letters published in recent issues of The Forestry Chronicle, there is a resurgent interest in, and concern about the roots of planted trees. The increasing production of container-grown trees might add a new twist to the potential problem, but concern about root aberrations imparted by nursery and/or planting practices was a subject of active discussion two or three decades ago when artificial reforestation methods were mounting to significant levels in Canadian silviculture. A detailed review is urgently needed of current and past experiences concerning imparted root aberrations as they affect future growth and stability of planted forests.

We are pleased, therefore, to provide a forum for such a review in May, 1978 (announced elsewhere in this issue). The detailed program of a "Symposium on the Root Form of Planted Trees" is still being developed, but we would like to outline our plans for the benefit of potential contributors and participants. We hope to enlist the help of Canadian and International investigators who have lengthy experience with planted forests, which have at times failed, but have, in many other circumstances, survived to harvestable age.

How common are root aberrations, and how do they compare with the root form of trees established from seed? What are the quantitative implications of imparted root "abnormalities" to ultimate yield? We anticipate that answers to the foregoing questions will vary according to nursery and planting practice, but will also vary with species, provenance, site, site preparation, and climate. A field trip to nearby forests will permit examination of limited local experiences. A concluding session will discuss practices and conditions that aggravate or alleviate potential root problems.

It is undoubtedly naive to consider that final answers will be forthcoming from one meeting, but at least contributors will bring together a comprehensive review of literature references on the subject.

Proceedings of the Symposium will be published promptly, with a microfiche supplement providing the opportunity for extensive illustrative material, and for inclusion of submitted papers from those 
who cannot attend, or from those who cannot be accommodated within the limited time available, or from investigators whom we may inadvertently overlook.

We are grateful to the Chronicle for helping stimulate the current concern about roots. We hope that its readers will help us report objective appraisals that will assist reforestation planners in this and other countries.

\section{E. Van Eerden \\ P. E. Robson}

J.M. Kinghorn

J.T. Arnott

(Root Symposium Organizing Committee)

\section{Back to the basics, once more}

This letter was prompted by two considerations. Firstly, because the initial letter that appeared under the heading "Back to the basics" in the August, 1976, issue of the Chronicle has been met with an almost total silence. Secondly, because of the single opinion expressed so far, namely, that even if periodic volume increments should be conservative because of underestimated height growth, relativities between responses to stand treatments would be maintained (Morrison et al., 1977). Both the non-response and the response make me wonder about the success of the initial letter. Thus, a new approach on my part is warranted. The initial letter stressed the importance of an upward shift in the height-diameter relationship with age in even-aged stands. So does this letter.

The results of 5-year growth measurements in 30 installations of the Interprovincial Forest Fertilization Program (Weetman, G.F. and H.H. Krause 1976) include both basal area and volume per ha of untreated stands, and these allow the calculation of form-heights and their increments. The current annual increments in form-heights range from only 0.6 to $4.2 \mathrm{~cm}$, with an average value of only $2.17 \mathrm{~cm}$. In my opinion, the current annual increments in form-height are too low in absolute values; they are also too low in terms of the mean annual increments in form-height that range from 6.3 to $19.2 \mathrm{~cm}$, with an average value of $11.74 \mathrm{~cm}$. The average value of the current annual increment in form-height is only $18.5 \%$ of the average value of the mean annual increment in form-height, while the corresponding figure for basal area increment is $103.3 \%$. I believe that the low form-height increments obtained result from the use of a single height-diameter curve at both measurement dates.

This belief is supported by examining some reported form-height increments available from other publications. For instance, the current annual form-height increment of jack pine, siteclass 1 , initial age 45 years, is $9.2 \mathrm{~cm}$ according to Plonski's (1974) yield tables, as compared with $3.0 \mathrm{~cm}$ for intreated stands in Ontario Installation 5 for jack pine. Table 1 presents the published 5 -year increments in total volume for this installation (line 1), and the corresponding increments if a $46 \mathrm{~cm}$ form-height increment had been obtained (line 6) instead of the $15 \mathrm{~cm}$ increment, assuming that both the untreated and treated stands had the same initial basal area, form-height, and consequently the same initial volume. Lines 2 and 7 show the response in volume increment of treated stands in relation to the untreated stands, and a comparison of these lines indicates that maintenance of relativities between volume responses cannot be assumed. Moreover, in the example given in "Back to the basics", the relative response also changed from 1.028 to 1.073 when two local volume curves were used instead of one.

In conclusion, I would like to repeat that in even-aged stands, the height-diameter relationship tends to move upward with age, with an associated upward shift in the local volume curves. The easiest and perhaps the only way to establish this upward shift is to take paired measurements of heights and diameters instead of random samples. This method would result in obtaining realistic estimates of the increment of both form height and stand volume.

F. Evert

\section{References:}

Morrison, I.K., H.S.D. Swan, N.W. Foster and D.A. Winston. 1967. Ten-year growth in two fertilization experiments in a semimature jack pine stand in northwestern Ontario. For. Chr. 53(3): 142-146.

Plonski, W.L. 1974. Normal yield tables (metric) for major forest species of Ontario. Ministry of Natural Resources, Division of Forests.

Weetman, G.F. and H.H. Krause. 1976. Interprovincial forest fertilization program - results of five-year growth remeasurements in thirty installations: fertilized in 1969, remeasured in 1974. Dep. Env., Can. For. Serv., For. Tech. Rep. 16.

Table 1. Growth data 1969-1974, jack pine

Final Value

\begin{tabular}{|c|c|c|c|c|c|c|c|c|}
\hline $\begin{array}{l}\text { Stand } \\
\text { Parameter }\end{array}$ & $\begin{array}{c}\text { Initial } \\
\text { Value }\end{array}$ & Untreated & $\mathrm{N}_{1}$ & $\mathrm{~N}_{2}$ & $\mathrm{~N}_{2} \mathrm{P}$ & $\mathbf{N}_{2} \mathrm{~K}$ & $\mathrm{~N}_{2} \mathrm{PK}$ & Line \\
\hline 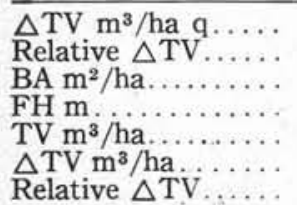 & $\begin{array}{c}28.5 \\
8.63 \\
246.0\end{array}$ & $\begin{array}{c}2.17 \\
1.000 \\
30.5 \\
9.09 \\
277.2 \\
31.2 \\
1.000\end{array}$ & $\begin{array}{c}32.1 \\
1.479 \\
31.5 \\
9.09 \\
286.3 \\
40.3 \\
1.292\end{array}$ & $\begin{array}{c}25.9 \\
1.194 \\
30.9 \\
9.09 \\
280.9 \\
34.9 \\
1.119\end{array}$ & $\begin{array}{c}28.6 \\
1.318 \\
31.2 \\
9.09 \\
283.6 \\
37.6 \\
1.205\end{array}$ & $\begin{array}{c}29.5 \\
1.359 \\
31.2 \\
9.09 \\
283.6 \\
37.6 \\
1.205\end{array}$ & $\begin{array}{c}28.3 \\
1.304 \\
31.1 \\
9.09 \\
282.7 \\
36.7 \\
1.176\end{array}$ & $\begin{array}{l}(1) \\
(2) \\
(3) \\
(4) \\
(5) \\
(5) \\
(7)\end{array}$ \\
\hline
\end{tabular}

